\title{
Generation Z Graduates Students' Perception towards Effectiveness of Hotel Exposure Training
}

\author{
T. S. Natarajan*, G. P. Raman \\ Department of Management Studies, SCSVMV University, India \\ Received March 22, 2019; Revised February 29, 2020; Accepted March 12, 2020
}

Copyright $\bigcirc 2020$ by authors, all rights reserved. Authors agree that this article remains permanently open access under the terms of the Creative Commons Attribution License 4.0 International License

\begin{abstract}
The Hotel Management Institute provides graduate students with basic skills and knowledge to be recruited and inducted as an entry-level workforce. Before completion of the graduate program, students undergo a Hotel Exposure Training program as part of their graduate study in luxury hotels which gives immense benefits to the students to know more about different functions of the hotel. There is always the perception changes with every graduates students from the time of enrollment to completion of the course. The critical phase is when the graduates students undergo the real time work exposure in the hotel. The research study explores the perception of Generation $\mathrm{Z}$ category undergraduate and graduate students. Generation $\mathrm{Z}$ are those born after the year 1996. The study focused on the effectiveness of hotel exposure training in terms of gaining confidence, understanding of the hotel operations and its influence, the student's perception on learning professional and technical skills, management practices, departmental functions, employment law and salary and benefit and to identify post-training employment opportunity. The study covered the Generation Z students of IHMC \& AN-Chennai, India. The study, conducted by survey method, found that, the perception of the generation $\mathrm{Z}$ graduate students on the different variables are positive except the long working hours, which the institute and the host hotel discuss and find solution through better training schedule. The majority of the preference for career choice is in core functions of the hotel. Regarding employment opportunity, there is a scope for the host hotel to identify the required talents in advance and pursue in campus interview.
\end{abstract}

Keywords Industrial Training, Hotel Management Students, Generation Z, Perception, Luxury Hotels, Workforce, Host Hotel, Artificial Intelligence and Analytics

\section{Introduction}

Hospitality Management education involves theory, practical and Hotel Exposure Training. With advancement in technology, the hotel and catering business process and practices change often. Hotels can afford to upgrade the technology and adapt to new practices and train its employees. To minimize the gap between academic curriculum and the learning by students about industry practice, every institution need to upgrade their curriculum, teaching methodology to prepare students to meet the employers' expectations and the growing demand for quality potential employees.

In India, the hotel management and catering technology graduate students undergo 17 to 22 week mandatory hotel exposure training, in five and four-star hotels to prepare them as hotel management professionals. The program is scheduled to undergo at the end of the second year of B.Sc course. The training covers, Front Office \& Accommodation Operation, Housekeeping, Food and Beverage Production, and Food and Beverage Service department. Each participant informed of his responsibilities before the start of the program. Each participant assessed by the hotel head of departments on completion of the training against the following attributes viz., Appearance, Punctuality/Attendance, Ability to Communicate (Written/Oral), Attitude to Colleagues/Customers, Attitude to Supervision, Initiative/Motivation, Reliability/Comprehension, Responsibility, Quality of Work and Ability to work under pressure. The management observations are sent to the Institute to provide necessary assistance to students where attention is required. But the study on perception of graduate students with reference to hotel exposure training is not explored. 


\subsection{Institute of Hotel Management \& Applied Nutrition- Chennai}

The Institute of Hotel Management Catering Technology and Applied Nutrition, (IHM \& AN) Chennai started in the year 1963. (An ISO 9001:2015 Certified Institute) (An Autonomous Body under Ministry of Tourism, Government of India) (Affiliated to NCHMCT, Noida and IGNOU, New Delhi). There are several values and job oriented programs ranging from 6 months of craft course to the Master of Science (M.Sc). Postgraduate degree program offered. To its credit, IHM Chennai produced many Hoteliers, Experts, Entrepreneurs, Top Executives working and settled across the globe and in India.

The study by "CEOWorld," included IHM\&AN-Chennai with an objective to rank the top 50 institutes around the world. The assessment was carried out against seven metrics like Perceived Global Brands Influence, Recruiters Responses, Employers Feedback, Job Placement Rate, Admission Eligibility, Specialization, and Academic Reputation. It is stated to be improvements over time lead to the stunning result that IHM\&AN-Chennai clinched 22nd rank among 50 institutions assessed by the quality of education, job placements of graduates, recruiters' response, employers' feedback, without relying on institutions data submissions.

\subsection{Statement of Problem}

There are numerous studies conducted to know the perception of hotel management students with regard to hotel exposure training in star hotels in India relevant to various factors viz., career, training satisfaction, duration, learning, support of supervisors, the structure of the program. There is no such study conducted with students from Institute of Hotel Management and Applied Nutrition, Chennai, with special reference to Generation $\mathrm{Z}$ graduates. The researcher identified the gap and undertook to study, examine, identify, know, analyze and interpret the perception through different key factors like Perception on Post Hotel Exposure Training, Job Opportunity in the Host Organization and Talents identified by the Management before Campus Recruitment.

\subsection{Need for the Study}

Hotel Management and Catering Technology Course is an extensive graduate program taught through theory and practice. The skill and knowledge development is limited, due to the time factor, available resource, infrastructure, and technology. To enhance the capability and gain confidence to complete the program successfully, the best way to impart training is through Hotel Exposure Training. The training makes the students feel the actual working environment and gain appropriate practical knowledge and skills taught by hotel experts. The learning from the hotel exposure training gives insight to students and complete their program with a good grade in theory, practical examination and ability to produce quality project thesis. The perception on hotel exposure training by generation $\mathrm{Z}$ graduate students gives the institute to understand the factors like Perception on Post Training, Job Opportunity in the Host Organization and Talents identified by the Hotel where the graduates underwent training.

\subsection{Objective of the Study}

- To study Generation Z Graduate Students of the IHM \& AN - Chennai, India, Perception towards Effectiveness of Hotel Exposure Training.

\subsection{Statement of Hypothesis}

H1 There is no positive perception about the Hotel Exposure Training among the Hotel Management Students in Chennai City.

$\mathrm{H} 2$ There is no significant distinction between male and female students concerning the Hotel Exposure Training among the Hotel Management Students in Chennai City

H3 There is no significant distinction among the age group of the respondents concerning the Hotel Exposure Training among the Hotel Management Students in Chennai city

\section{Research Methodology}

The present paper's specific objectives are to find out the "Generation Z" Hospitality Students' Perception towards Industrial Exposure Program: IHM - Chennai city. The sample size of the study is 106 respondents. The study used a simple convenience sampling method to generate a sample of the study. The hotel management students are requested to give the opinion in the questionnaire provided. The first segment of the questionnaire copy includes the demographic profile of the hotel management students, and the second segment of the questionnaire includes the perception of the hotel management courses - the data collected during March 2019. The data collected classified, tabulated, processed and analyzed systematical 1 y mainly to identify the group of determinants. The statistical tools namely one sample t-test, Independent t-test, and analysis variance test used to test the framed hypothesis.

\section{Literature Review}

In an attempt to evaluate the perception of having completed the internship in hospitality and tourism industry the James Bury and Emi Iwasaki (2018) [1] concluded that the students indicate an overall positive 
effect and the positive perception must be encouraged non-tourism graduates to take up a career in tourism \& hospitality industry. All tourism and hotel management have the opportunity to understand current students' attitudes and overall perception of the industry has undergone the program

The research study by Kannan Subbiah et al. (2017) [2] concluded that the industrial training program is well structured and students get the benefit from classroom learning in the institute and practical exposure in the work environment in the hotel. The program gives benefit like acquiring practical skills, an opportunity to exhibit their strength to be an eligible candidate for employment. The study revealed that the program is relevant to hotel management students' hotels and educational institutions work closely to strengthen the program.

Kiran Mayi Immaneni and Dr.Vedala Naga Sailaja (2017) [3] revealed that the effort to make the industrial training program positive and attractive is minimal in comparison with the overall effects of attrition. Hotel industry required to make the program with a view to long term advantage rather than considering industrial training students as cheap labor for a short time. The study concluded that the institute, host hotel, and professionals to review the responsibilities and roles to make the program more beneficial the future workforce of the industry.

Richard N.S. Robinson, Lisa Ruhanen \& Noreen M. Breakey (2016) [4] examined the Tourism and hospitality internships influences on student career aspirations, and the result confirmed that the most respondents did not change their career aspiration following the internship. However, their choice of career only within the industry changed. The study revealed that many respondents changed their career goal from the hospitality industry to tourism industry.

The research study by Amit Datta and Dr.Babita Jha (2015) [5] concluded that students benefited through the daily learning environment, colleagues helpful during a training program in teaching various skills. The research highlighted that students underwent training in five-star hotels enjoyed their facility provided by the host hotel than a lower class hotel. The perception regarding career growth and choice of career changed after attending the program. The students found that education is fundamental and the career depends on quality experience in hotels.

According to Kingsley Karunarante \& Niroshani Perera (2015) [6] the findings of the study on the effectiveness of internship program concluded that the students' learning experience is good or excellent are the chance to build up a relationship with hotels, acquire hotels work culture, develop self-confidence, executive problem-solving activities, develop social interaction skill, and aspire future education and career. Hotels support in pre-placement activities and assist with the support of the institute or university. Further, the study found that students perceive that the industrial exposure program to be twelve months.
The research study by Raheshree S. Pol and Hemraj Patil (2015) [7] on the perception of the final year students concluded that the attitude of the students' changes after attending industrial exposure training in hotels. Many students are satisfied with the hotel employment culture, and there is an uncertain situation for many students to take up employment in hotels, after attending the program. There is a shift in perception when expectation as being a student not fulfilled. It revealed that students of the opinion that the average promotion opportunities in hotel jobs and the career offered is not attractive. The hotel management students the pay level is higher than other jobs, and it is worth undergoing hotel management studies. On the other side of the work and pay the students of the opinion that there are long hours of work without additional pay.

In an attempt to evaluate the impact of industrial training by Sundar Srinivsan and Rajeshree Pol (2014) [8] concluded that the hotel management trainees welcomed by most of the hotels in Pune. The human resource department found that Hotel management students display the right attitude towards work and also have ethics and spend lesser time in terms of training compared to other schools or institutions. Training program saves not only future recruitment and hiring time but also proves financial benefits for fulfilling temporary staffing needs. The study reveals that the feedback from industry personnel helps in effective practical curriculum planning which can be followed by the institutes to develop the skills of their students. Hotel expressed that, not much effort exerted in training the students as the students coming from this school were very adaptable as they have sufficient knowledge to perform task and duties assigned to them.

The relevant study to the research by Anoop Kumar et al. (2014) [9] on changing the perception of students towards the hospitality industry revealed that there is a definite perception by first-year students. The study found that there is a significant difference of opinion between the first year and final year students after attending the industrial training program. The study reveals that there is negative perception after undergoing the training on certain points which needs attention by the host hotels to make the program enriching and enjoyable.

The research study by S.M.Denis Amirtharaj (2011) [10] aimed at training and development activities in the hotel industry, reveals that human resource department is responsible for giving proper training and better career opportunities for their future. Every employee should be aware of the facts of this industry before they join in so that they mentally prepared for everything. While the study focused on the training, the same fact holds good and relevant for the graduates who are going to join the hotels after completion of the program. Thus it is established that the findings also concerned with industrial exposure trainees.

The findings of research study by Dr.Jayakumar.V(2011) [11] reveals that the knowledge 
of the hotel operation through exposure training helps to understand the industry and influence their choice of career in particular department before getting hired. The findings also highlighted that the students perceived that communication skill is very important to take up a career in star hotels.

\section{Data Analysis and Interpretation}

Table 1. Demographic Profile of Respondents

\begin{tabular}{|c|c|c|}
\hline Demographic Profile & Frequency & Percent \\
\hline \multicolumn{3}{|l|}{ Gender } \\
\hline Male & 75 & 70.8 \\
\hline Female & 31 & 29.2 \\
\hline Total & 106 & 100.0 \\
\hline \multicolumn{3}{|l|}{ Age Group } \\
\hline $17-18$ Yrs & 2 & 1.9 \\
\hline 18-19 Yrs & 22 & 20.7 \\
\hline $19-20$ Yrs & 40 & 37.7 \\
\hline $20-21$ Yrs & 22 & 20.8 \\
\hline $21-22$ Yrs & 13 & 12.3 \\
\hline $22-23$ Yrs & 7 & 6.6 \\
\hline Total & 106 & 100.0 \\
\hline \multicolumn{3}{|c|}{ Current Program - Under Study } \\
\hline Hotel Mgmt Bachelor Degree & 97 & 91.5 \\
\hline Hotel Mgmt Masters Degree & 9 & 8.5 \\
\hline Total & 106 & 100.0 \\
\hline \multicolumn{3}{|c|}{ No. of Years of previous Job Experience } \\
\hline Fresher & 103 & 97.2 \\
\hline 3-5 Yrs & 3 & 2.8 \\
\hline Total & 106 & 100.0 \\
\hline \multicolumn{3}{|c|}{ Stipend Received Per Month (INR/US \$) } \\
\hline Less than $5000 / 70$ & 101 & 95.3 \\
\hline $5000 / 70-5500 / 80$ & 2 & 1.9 \\
\hline $6000 / 85-6500 / 95$ & 1 & 0.9 \\
\hline Above 9000/130 & 2 & 1.9 \\
\hline Total & 106 & 100.0 \\
\hline \multicolumn{3}{|c|}{ Expected Annual Salary (INR / US \$) - First year of Employmen } \\
\hline Less than Lac / 1400 & 20 & 18.9 \\
\hline $1 \mathrm{Lac} / 1400$ & 4 & 3.8 \\
\hline 1.5 Lac / 2150 & 5 & 4.7 \\
\hline $2 \mathrm{Lac} / 2857$ & 6 & 5.7 \\
\hline $2.5 \mathrm{Lac} / 3570$ & 9 & 8.5 \\
\hline $3 \mathrm{Lac} / 4300$ & 19 & 17.9 \\
\hline Above 3 Lac / Above 4300 & 43 & 40.6 \\
\hline Total & 106 & 100.0 \\
\hline
\end{tabular}

Table 1 shows the Demographic Profile of Respondents. Out of 106 respondents, $70.8 \%$ of respondents were male, and $29.2 \%$ of respondents were female. In connection with the age-wise distribution of respondents, majority $37.7 \%$ of respondents were in the age group of 19-20 years, followed by $20.8 \%$ of respondents were in the age group of $20-21$ years. $20.7 \%$ of respondents were in the age group 18-19 years, $12.3 \%$ of respondents were in the age group 21-22 years, $6.6 \%$ of respondents were in the age group 22-23 years, and $1.9 \%$ of respondents were in the age group $17-18$ years.

Regarding the current program - Under Study's concern, 91.5\% of the respondents pursuing Hotel Mgmt Bachelor Degree, and $8.5 \%$ of the respondents pursuing Hotel Mgmt Masters Degree. As for as the number of Years previous Job Experience of respondents, majority $97.2 \%$ of the respondents are fresher's, followed by $2.8 \%$ of the respondents are having 3-5 years of experience.

The stipend received per month of the respondents' concern, the majority $95.3 \%$ of the respondents received a stipend up to Rs.5,000 (\$70), followed by $1.9 \%$ of the respondents received stipend Rs. 5000 (\$70) - 5500 (\$80), 0.9 of the respondents received stipend Rs.6000 / (\$85) 6500 / (\$95), and $1.9 \%$ of the respondents received stipend Above Rs.9000 (\$135).

Regarding the expectation of annual salary's concern, majority $40.6 \%$ of the respondents expected salary annually Above 3 Lakh, (\$4300) followed by $18.9 \%$ of the respondents expected salary annually less than a Lakh, (\$1400), $17.9 \%$ of the respondents expected salary annually Rs.3 Lakh, (\$4300), 8.5\% of the respondents expected salary Rs.2.5 Lakhs (\$3570), 5.7\% of the respondents expected salary Rs. 2 Lakhs, (\$2857), 4.7\% of the respondents expected salary Rs. 1.5 Lakh (\$2150) and $3.8 \%$ of the respondents expected salary one lakh $(\$ 1400)$.

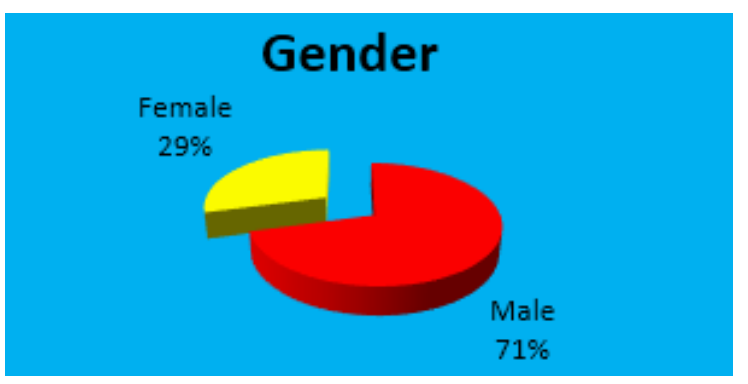

Chart 1. Gender category of Respondents

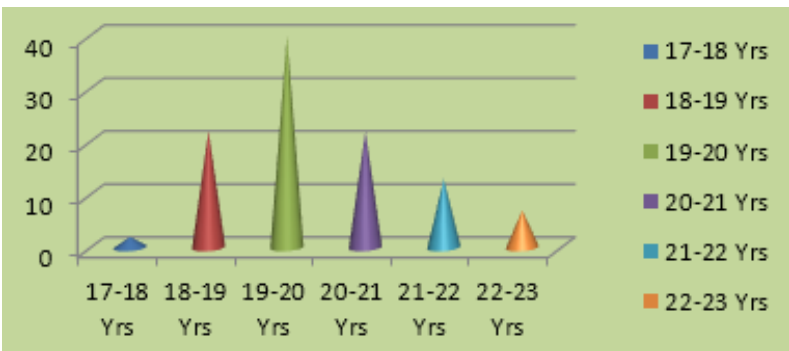

Chart 2. Percentage of Students enrolled in Bachelor Degree and Masters Degree program 


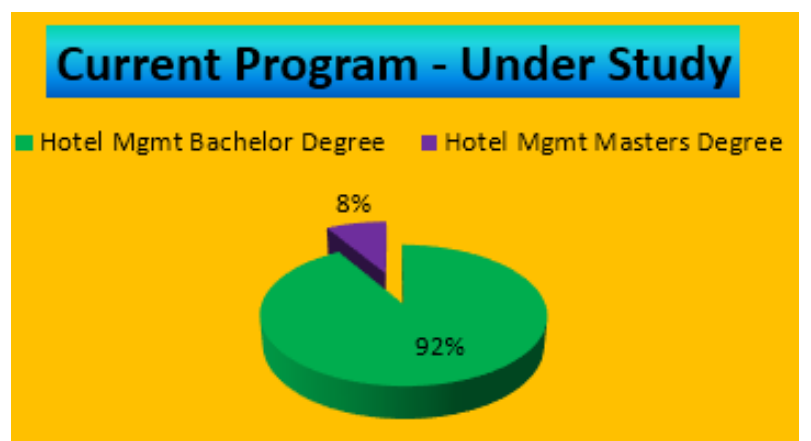

Chart 3. Percentage of Student underwent Hotel Exposre Training in 5 and 4 Star Hotels

Table 2. Industrial Training Underwent by the Students

\begin{tabular}{|c|c|c|}
\hline Hotels & Frequency & Percent \\
\hline 5 Star & 82 & 77.4 \\
\hline 4 Star & 24 & 22.6 \\
\hline Total & 106 & 100.0 \\
\hline
\end{tabular}

Table 2 reveals the Industrial Training Underwent by the Students in the study region. It identified from the above table, the majority $77.4 \%$ of the respondents underwent industrial training in 5-star hotels, followed by $22.6 \%$ of the respondents underwent industrial training in 4-star hotels.

Table 3. Preference of Department by Respondents

\begin{tabular}{|c|c|c|}
\hline Department & Frequency & Percent \\
\hline Front Office & 29 & 27.4 \\
\hline Housekeeping & 14 & 13.2 \\
\hline F \& B Service & 17 & 16.0 \\
\hline F \& B Production & 36 & 34.0 \\
\hline HR & 9 & 8.5 \\
\hline Sales & 1 & .9 \\
\hline Total & 106 & 100.0 \\
\hline
\end{tabular}

Table 3 shows the respondents' preference to take up a career in hotels in the study area. It noted from the above table $34 \%$ of the respondents' preference is food and beverage production, followed by $27.4 \%$ of the respondents is front office. The third preferred area with $16.0 \%$ of the respondents is food and beverage service department in star hotels, $13.2 \%$ of the respondents are housekeeping department in star hotels, $8.5 \%$ of the respondent's interest in the HR department in hotels, and $0.9 \%$ of the respondent's preference is in sales department of hotel industry.

\section{Null Hypothesis-1}

There is no positive perception about the Hotel Exposure Training among the Hotel Management Students in Chennai City.

Table 4. One-sample t-test for whether there is any positive perception about the Hotel Exposure Training among the Hotel Management Students in Chennai city

\begin{tabular}{|c|c|c|c|c|c|}
\hline & $\mathrm{N}$ & Mean & Std. Deviation & t-value & $\mathrm{p}$-value \\
\hline $\begin{array}{c}\text { Overall Perception } \\
\text { of the Hotel } \\
\text { Exposure Program }\end{array}$ & 106 & 2.2255 & .38534 & 59.461 & $<0.001 * * *$ \\
\hline
\end{tabular}

Table 4 highlights the results of One-sample t-test for whether there is any positive perception about the Industrial Exposure Program among the Hotel Management Students in Chennai city. The calculated t-value and p-value are 59.461 and $<0.001$, therefore the null hypothesis rejected at $1 \%$ level of significance. The study confirmed that there is a significant positive perception of the Industrial Exposure Training among the Hotel Management Students in Chennai city.

\section{Null Hypothesis-2}

There is no critical distinction between male and female students concerning the Hotel Exposure Training among the Hotel Management Students in Chennai City

Table 5 shows the results of Independent t-test for whether there is an essential distinction between male and female students concerning the Hotel Exposure Training among the Hotel Management Students in Chennai city. The calculated t-value is 0.022 and p-value 0.983 , due to these circumstances the null hypothesis accepted at $5 \%$ level. The study concluded that there is no significant distinction between male and female students concerning the Industrial Exposure Program among the Hotel Management Students in Chennai city

Table 5. One-sample t-test for whether there is any positive perception about the Hotel Exposure Training among the Hotel Management Students in Chennai city

\begin{tabular}{|c|c|c|c|c|c|c|}
\hline & Gender & $\mathrm{N}$ & Mean & Std. Deviation & $\mathrm{t}$-value & $\mathrm{p}$-value \\
\hline \multirow{2}{*}{$\begin{array}{l}\text { Overall Perception of Hotel exposure } \\
\text { Training of Hotel Management }\end{array}$} & Male & 75 & 2.2260 & .42833 & \multirow{2}{*}{0.022} & \multirow{2}{*}{0.983} \\
\hline & Female & 31 & 2.2242 & .25912 & & \\
\hline
\end{tabular}




\section{Null Hypothesis-3}

There is no significant distinction among the cohort of the respondents concerning the Hotel Exposure Training among the Hotel Management Students in Chennai City

Table 6. ANOVA test for whether there is a significant distinction among the cohort of the respondents concerning the Industrial Exposure Program among the Hotel Management Students in Chennai city

\begin{tabular}{|c|c|c|c|c|c|}
\hline Age group & $\mathrm{N}$ & Mean & $\begin{array}{c}\text { Std. } \\
\text { Deviation }\end{array}$ & F-value & $\mathrm{p}$-value \\
\hline 17-18 years & 2 & 2.1750 & .67175 & & \\
\hline $18-19$ years & 22 & 2.2727 & .26310 & & \\
\hline 19-20 years & 40 & 2.1575 & .34725 & \multirow{2}{*}{0.830} & \multirow{2}{*}{0.531} \\
\hline 20-21 years & 22 & 2.3318 & .50510 & & \\
\hline 21-22 years & 13 & 2.2538 & .43275 & & \\
\hline 22-23 years & 7 & 2.0929 & .35523 & & \\
\hline
\end{tabular}

Table 6 shows the results of the Analysis of variance test for whether there is a significant distinction among the cohort of the respondents concerning the Hotel Exposure Training among the Hotel Management Students in Chennai city. The calculated F-value and p-value is 0.830 and 0.531 ; the p-value is higher than 0.05 . Therefore, the null hypothesis accepted at 5\% level and concluded that there is no significant distinction among the cohort of the respondents concerning the Industrial Exposure Training among the Hotel Management Students in Chennai city.

\section{Findings}

The demographic profile of generation $\mathrm{Z}$ graduate students reveals $70.8 \%$ are male and $29.02 \%$ are female students. The Bachelor Degree program has $91.5 \%$ students and Master Degree program has $8.5 \%$ students. $40.6 \%$ of the students stated the expected salary after completion of the program is above 3 lacs (above \$4300). It is found from the analysis that $77.4 \%$ of the students underwent hotel exposure training in five star category hotels and $22.6 \%$ underwent in four star category of hotels. The study establishes $34.0 \%$ of students preferred to take up job in food production department. 29\% preferred to take up job in front office department. The least being $0.9 \%$ preferred to take up job in sales department.

The study found that there is a positive perception of the Industrial Exposure Training among the Hotel Management Generation Z Graduate Students. The study concluded that there is no significant distinction between both the gender of students concerning the Hotel Exposure Training. From the study confirms that there is no significant distinction among the cohort of the respondents concerning the Hotel Exposure Training among the Hotel Management Generation Z Students.

\section{Suggestions}

The finding of the study recommends the following points to give an opinion that hotel employment is on par with other industries.

1. The Institute conduct survey of perception from Craft Course students underwent Hotel Exposure Training

2. The institute may conduct survey of perception about comparison of pre-training and post-training and find out the cause and effect relationship.

3. Periodical lecture by top management and human resource manager of the host hotel to explain industry practice, job requirement, and career prospects.

4. Host Hotels may get the feedback from the Institute for considering any change in the employment policies.

\section{Conclusions}

It observed that the study concluded that there is a significant positive perception about the Hotel Exposure Training among the Generation $\mathrm{Z}$ Graduate Students of IHM Chennai. The study confirms that there is no significant distinction among the cohort of the respondents of male and female students concerning the Hotel Exposure Training.

The study confirms that the Hotel Exposure Training influenced the students' perception regarding career choice, respondents favor that there is an opportunity to get hired by the same hotel where students underwent training, the majority of students developed awareness about salary and benefits and learned about employment regulations of the hotel. The study reveals that hotel management takes this opportunity to identify talents in advance to hire during the campus interview.

\section{Scope for Further Research}

This study creates an avenue for further research. Further research can address the following factors to have more insights on the students' perception. How the use of high-end technology, artificial intelligence, and analytics in core operation influence the students of Hotel exposure training impact on the decision to take up a career in hotels. Further to find out how technology awareness influences the perception of students about hotel industry jobs and students interest in learning newer technology.

\section{Website Reference}

http://www.ihmchennai.org http://www. ceoworld.biz 


\section{REFERENCES}

[1] James Bury and Emi Iwasaki (2018) The Impact of Having Completed Internships on Undergraduate Students' Perceptions of the Japanese Tourism and Hospitality Industry - Asia Pacific Journal of Innovation in Hospitality and Tourism APJIHT - Volume - 7 No.1 - March 2018 pp

[2] Kannan Subbiah et al. (2017) -Undergraduate Students Perception on Industrial Training- International Journal of Business and Management Inventions Volume-6, Issue-7 July 2017 PP-72-76

[3] Kiran Mayi Immaneni and Dr.Vedala Naga Sailaja (2017) Industrial Exposure Training in Hotels and its Impact on undergraduates - Challenges and Remedies - International Journal of Mechanical Engineering and Technology (IJMET) - Volume 8 Issue 12, December 2017, pp 834-840

[4] Richard N.S. Robinson, Lisa Ruhanen \& Noreen M. Breakey (2016) - Tourism and hospitality internships: Influences On Student Career Aspirations. - Journal Current Issues in Tourism Volume 19, 2016 - Issue 6-Pages 513-527 | 13 Mar 2016

[5] Amit Datta \& Dr.Babita Jha (2015) Industrial Training and its consequences on the career perception - A Study in context of the Hotel Management Students at Jaipur.EPRA International Journal of Economic and Business Review - www.epratrust.com -Volume-2, Issue-2 February 2015

[6] Kingsley Karunarante \& Niroshani Perera (2015) "Students' Perception on the Effectiveness of Industrial Internship Program" - Proceedings of the International Conference on Global Business, Economics, Finance, and Social Science - Bangkok, Thailand.- 20-22 2015 Paper ID T5118.

[7] Raheshree S. Pol and Hemraj Patil (2015) - Perception of Final Year Hotel Management Students towards Working in Hotel Industry - Athithya A Journal of Hospitality Volume - 1, Issue-2, 2015 pp 46-53.

[8] Sundar Srinivsan and Rajeshree Pol (2014) - Study on the importance of Industrial Training as part of Hotel Management Education Curriculum, $\mathrm{s}$ perceived by industry and students. - International Journal of Informative \& Futuristic Research - Volume-1 Issue-9, May 2014

[9] Anoop Kumar et al. (2014) - Changing Perception of Students Towards Hospitality Industry: A Comparative Analysis - International Journal of Tourism and Hospitality Reviews. Volume-1 (1) November 2014 - pp 10-17

[10] S.M.Denis Amirtharaj (2011) HR Concepts in Hotel Industry Towards Employee Training and Development International Journal of Human Resource Management and Research - Vol.1, Issue - 1, (2011) pp 44-46

[11] V. JayKumar et al (2011) - Hotel Career Perceptions of Final Year Hospitality Degree Students - Research Article American Scientific Publishers - Vol. 4, 400-407 